\title{
ВІДОМОМУ ІНФЕКЦІОНІСТУ, ПРОФЕСОРУ О.М. ЗІНЧУКУ ВИПОВНИЛОСЯ 60 РОКІВ
}

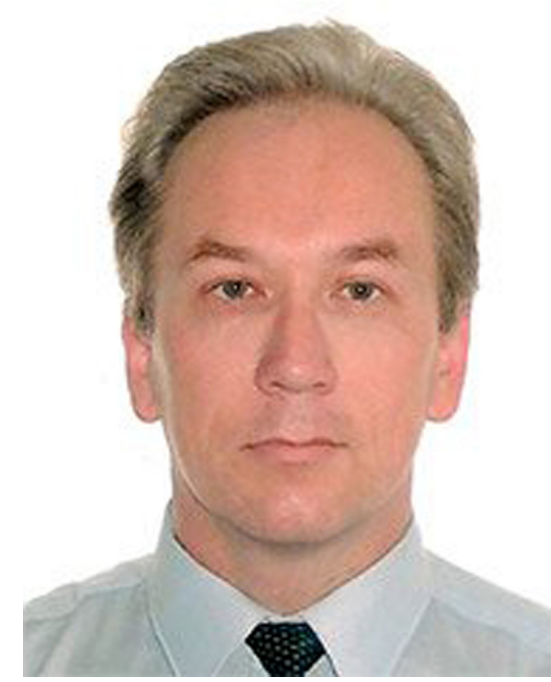

Стисло висвітлено основні біографрічні віхи й творчий доробок профресора О.М. Зінчука - відомого лікаря-інфрекціоніста, педагога, науковця, завідувача кафредри інфекційних хвороб Львівського національного медичного університету імені Данила Галицького.

11 лютого 2019 р. виповнилося 60 років із дня народження Олександра Миколайовича Зінчука - знаного інфрекціоніста, доктора медичних наук, профресора та завідувача кафредри інфекційних хвороб Львівського національного медичного університету імені Данила Галицького.

Олександр Миколайович народився 11 лютого 1959 р., у м. Львові в родині педагогів. Батько - Микола Антонович Зінчук - видатний фольклорист, збирач українських народних казок, казкар; історик. Педагог зібрав, упорядкував та літературно опрацював збірку «Українські народні казки» у 40 томах. Від батьків Олександр Миколайович успадкував нестримну жагу до знань, постійного самовдосконалення та наукових досліджень.

Лікарську освіту професор Зінук О.М. здобував у ЛДМІ з 1976 по 1982 рр. Після чого, з 1992 по 1994 рр., продовжив навчання в аспірантурі на кафедрі інфрекційних хвороб лДМІ. Свою професійну діяльність розпочав лікарем-інфекціоністом Рокитнівської ЦРЛ Рівненської області, де працював з 1982 по 1999 рр. Продовжив професійну кар'єру на посаді лікаря-інсрекціоніста Городоцької ЦРЛ Львівської області. Але постійне бажання до розвитку та наукової роботи привело Олександра Миколайовича на кафредру інфекційних хвороб лдМІ, де він з 1994 р. працював на посаді асистента. У 1994 р. успішно захистив наукову роботу на тему «Сезонні особливості перебігу вірусних гепатитів» і отримав науковий ступінь кандидата медичних наук, продовжив роботу на посаді доцента кафедри. У цей період Олександр Миколайович проводить низку досліджень, присвячених проблемі клініки, епідеміології та профрілактики Лайм-бореліозу. Результати цих досліджень були успішно представлені у дисертації на тему «Лайм-бореліоз: клінікоімунопатогенетичні особливості та екстрене превентивне лікування», яку він блискуче захистив у 2010 р. й отримав науковий ступінь доктора медичних наук, а згодом - вчене звання професора. У результаті наполегливої праці 3 2005 р. професор Зінчук О.М. очолив кафредру інфекційних хвороб лНМУ ім. Данила Галицького де продовжує успішно та плідно працювати.

За період своєї роботи на кафредрі іноекційних хвороб Олександр Миколайович щедро ділився своїми знаннями з молодими лікарями, науковцями та виховав цілу плеяду наукових співробітників.

Різноманітною $є$ палітра наукових досліджень Олександра Миколайовича, яка включає: питання діагностики та лікування вірусних гепатитів, черевного тифу, дифртерії, паразитозів, Лайм-бореліозу, Clostridium difficile-інфекції.

Вагоме науково-практичне значення мають наступні роботи, які присвячені найбільш актуальним питанням інфректології:

- Актуальні питання клініки, діагностики та лікування нейробореліозу.

- Лайм-бореліоз у Львівській області: спроба екологоепідеміологічного аналізу.

- Можливості екстреної профрілактики Лайм-бореліозу.

- Congenital visceral leishmaniasis in Ukraine: case report.

- Лістеріозний менінгіт: труднощі діагностики і лікування.

- До питання про екстрену профрілактику Лаймбореліозу.

- Ураження щитоподібної залози у хворих на хронічний гепатит C на тлі противірусної терапії: діагностика і лікування. 


\section{ЮВІЛЕї ТА ПОДІї}

- Токсоплазмоз головного мозку в імунокомпетентних осіб.

- Безсимптомний перебіг Лайм-бореліозу у робітників профресійних груп із високим ризиком зараженням.

- Сучасні аспекти Clostridium difficile-інфрекції.

Наукові здобутки профр. Зінчука О.М. широко висвітлені більше ніж у 200 наукових роботах та 10 патентах.

Високопрофресійно й натхненно проводить проф. Зінчук О.М. лекції, практичні заняття та семінари для студентів і лікарів-курсантів ФПдО. За роки самовідданної праці йому довелося навчати сотні студентів і лікарів-курсантів. Багато теперішніх викладачів і професорів ЛНМУ - це колишні учні Олександра Миколайовича. Профресор Зінчук Олександр Миколайович зробив значний внесок у розвиток української іноректології, бере активну участь у роботі міжнародних і регіональних науково-практичних конореренцій.

Олександр Миколайович успішно поєднує плідну науково-педадогічну та організаційну роботу: є членом редколегії науково-практичних журналів. Бере активну участь у роботі Всеукраїнського науково-практичного товариства інорекціоністів. Впродовж багатьох років $є$ головою товариства інфрекціоністів Львівської області, користується заслуженим авторитетом і повагою колег.

Олександр Миколайович не лише видатний науковець і педагог, але й досвідчений лікар-клініцист, має вищу категорію за фрахом «Інфрекційні хвороби». Завдяки його невтомній, самовідданій праці сотні пацієнтів одужали і повернулися до повноцінного життя. Визнанням великих заслуг профресора Зінчука О.М. як практикуючого, досвід ченого клініциста $€$ призначення його у 2018 р. відповідальним за лікувально-профрілактичну роботу Львівського національного медичного університету ім. Данила Галицького.
Свій ювілей Олександр Миколайович зустрічає повним сил та енергії, з новими науковими ідеями та творчими планами.

Колектив кафедри інфекційних хвороб ЛНМУ ім. Данила Галицького, друзі та учні сердечно поздоровляють профресора Зінчука Олександра Миколайовича з ювілеєм, бажають йому нових творчих успіхів, здоров'я і довгих років активного життя.

Президія Всеукраїнської асоціації інфрекціоністів, колектив кафредри інфрекційних хвороб

Львівського національного медичного університету імені Данила Галицького, Редакція журналу «Інфрекційні хвороби».

\section{PROMINENT INFECTIOUS DISEASE DOCTOR, PROFESSOR O.M. ZINCHUK IS 60 YEARS OLD}

SUMMARY. The main biographical milestones and creative work of Professor O.M. Zinchuk is a well-known infectious disease doctor, teacher, scientist, head of the Department of Infectious Diseases of the Danylo Halytsky Lviv National Medical University.

Конфрлікту інтересів немає.

Authors have no conflict of interest to declare.

Отримано 8.02.2019 p 